\title{
Methodological Foundations of the Problem of Parts of Speech in Linguistics
}

\section{Dilfuza Sayidmahamadzhanovna Saiidyrakhimova', Kulubekova Azarabu Omorakunovna ${ }^{2}$ \\ Kadyrova Mukadam Saydamovna ${ }^{3}$ \\ Sayidirahimova Nasiba Sayidmahamadovna ${ }^{4}$}

Abdyrakmanova Gulsun Mamatovna ${ }^{5}$

${ }^{1}$ PhD in Philology, Associate Professor of the Kyrgyz-Uzbek University

Osh, Kyrgyzstan.

Ossu.oms@gmail.com

${ }^{2}$ PhD in Philology, Associate Professor Osh State University

Osh, Kyrgyzstan.

${ }^{3}$ Candidate of Pedagogical Sciences, Associate Professor, Professor of RAE

Head of the Department of PiMDiNO.

Osh, Kyrgyzstan.

${ }^{4} \mathrm{PhD}$ in Philology, Associate Professor

International Islamic Academy of Uzbekistan.

Tashkent, Uzbekistan.

E.mail: sayidirahimova@navoiy-uni.uz.

${ }^{5}$ Lecturer at Batken State University.

Batken, Kyrgyzstan.

\section{Annotation}

Morphology is directly different from other levels of the language. This is due to the fact that word groups and their specific grammatical categories are the most important issues in the formation of speech. Therefore, the morphological units of the language have been of interest to linguists from the very beginning of linguistics, and even now the study of issues related to the problems of morphology, as well as extensive scientific analysis in the morphological aspect, continues on the basis of new paradigms of the language.

Given this, this article is devoted to the study of parts of speech in linguistics, which is one of the most pressing problems of modern general linguistics. It examines the extralinguistic and intralinguistic foundations of the formation of adverbs in the languages we study. When studying and analyzing these issues, we used methods of comparison, description, as well as thematic analysis.

Key words

extrolinguistics, introlinguistics, lexical classification, criteria, component analysis method.

\section{Introduction}

Currently, a radical change is taking place in linguistics, that is, the study of linguistic phenomena within the framework of a scientific paradigm, as a result of which it became clear that it is important to look at linguistic phenomena from a new cognitive, anthropocentric point of view. As a result, many new areas of linguistics 
began to develop rapidly, such as cognitive, anthropocentric, associative linguistics $[7,11,13,22,24]$. However, theoretical concepts of the grammatical foundations of the language still serve as the methodological basis of modern linguistics. For this reason, the study and generalization of the scientific basis of units of the morphological level of the language is still relevant for us today $[14,15,16,17,21,23,25]$.

\section{Main part}

Some linguists define parts of speech as a lexical category, lexical classification of words, as an invariant of a subject-logical plan. Others believe that parts of speech are logical categories of words and therefore morphological features are of decisive importance in identifying parts of speech. However, this criterion is unsuitable for languages with a poorly developed morphological system [6,7, 1, 18,19,20].

A.A. Reformatsky in his works defined parts of speech as grammatical categories (and not lexical or lexical-grammatical), the composition of which is individual in each language and is determined by a set of morphological and syntactic properties. Some linguists, on the other hand, believe that the meanings of parts of speech are their main feature, and the basis for identifying parts of speech is their lexical-semantic features, generalizing categorical meanings. [2, 124]. Finally, parts of speech are considered as lexical and grammatical categories of words that differ from each other not only in a number of grammatical features (morphologically - in mutability and immutability, in a way of change, in paradigmatics; syntactically - in ways of communication with other words, and a syntactic function), but also lexically ... This point of view is the most accepted in modern Russian linguistics $[10,11,12]$.

An approach to the problem of parts of speech is possible based on the concept of functional-semantic word categories. Words that function as nouns, adjectives, pronouns, verbs, numerals, adverbs, etc., are found in all languages of the world. The presence of categorical meaning and certain functions fully ensures the existence of functional and semantic categories in the language $[6,8]$.

Questions related to the theory of parts of speech remain controversial; there are discrepancies regarding the quantity, nomenclature, as well as criteria for the selection of parts of speech. Linguists of foreign and domestic grammar Henry Sweet, the author of the first scientific grammar, put forward three basic principles of word classification: meaning, form and function of a word. He divided the parts of speech into two main groups - changeable and unchangeable, raising the morphological form to the rank of the leading classification criterion $[3,161 ; 167]$. Within the group of declinables, he followed the traditional approach of nouns, adjectives, and verbs. Adverbs, prepositions, conjunctions and interjections are combined into the group of unchangeable (indeclinables). Along with this classification, Sweet offers a grouping based on the syntactic functioning of certain word classes. Thus, the group of nominal words (noun words) includes, in addition to nouns, nominal pronouns (noun-pronoun-noun-pronouns), nominal numerals (noun-numeral-noun-numerals), infinitives and gerunds; the group of adjective words includes, in addition to adjectives, adjective pronouns (adjective-pronoun-adjective-pronouns), adjective numerals (adjective-numerals adjectivenumerals), participles. The verb group includes personal forms and verbs; here again the morphological criterion is in the lead; all impersonal forms, like personal ones, have verb categories of tense and liens. Thus, the verbals the infinitive and the gerund - are assigned to nominal words on the basis of their syntactic functioning, and by their morphological properties they also appear in the verb group.

The classification of the representative of the classical school of grammar Otto Jespersen is 
also based on three principles: form, function and meaning. He criticizes almost all traditional definitions of parts of speech. O. Espersen also questions the distinction between conjunctions and prepositions as independent parts of speech. In his classification, $O$. Espersen distinguishes the following parts of speech: 1) a noun, 2) an adjective, 3) pronouns, 4) verbs, 5) particles, which include all other words lacking the ability to form. The author insists that the distinction between words from group 5 is greatly exaggerated. However, O. Jespersen sees the difference between the compositional and subordinate unions and calls the compositional unions the compositional connectors, and the subordinate unions and prepositions - the subordinate connectors [4:148,152].

Interjections also fall into group 5 . Jespersen analyzes this class of words in an interesting way, noting the features of interjections, for example, the presence in them of such sounds that are absent in the phonemic composition of an unrelated language: aspirated bilabial (f) and aspirated (x).

Thus, although the scientist proposes to take into account all three signs of highlighting parts of speech, in his classification it turns out to be inconsistent.

Along with the above classification, Espersen proposed an analysis of word classes from the point of view of their functioning in syntactic combinations (phrases, sentences), which is called the theory of three ranks. This or that word can be primary, i.e. be the core of a phrase, a sentence, another word may be secondary, i.e. directly defining the primary, another word - tertiary, i.e. subordinate to the secondary.

Representatives of foreign linguistics of the middle of the twentieth century, descriptive structuralists, put forward a fundamentally new approach to the problem of classifying parts of speech. They opposed taking into account the role of meaning in linguistic analysis $[6,8,9]$.

Structuralists believed that the classification should be based only on signs of the position of a word in a sentence. [7,10,11,12]. A typical classification of this type can be considered the classification of the American structuralist Charles Fries, given by him in the book "The Structure of Language". He draws attention to the fact that even in a meaningless sentence, it is possible to establish the belonging of a word to certain grammatical categories - parts of speech. This can be established by the position that the words occupy in the sentence, and by their form as opposed to other positions and forms.

\section{Выводы}

In order to find out what positional classes of words exist in the language, it is necessary to find out what positions are basic. For this purpose, C. Freese selects a limited number of sentences, which he calls "test frames", and within these frames determines the basic positions characteristic of words. Using the method of substitution, Freese, within each test box, identifies words that can occupy a certain position in a sentence. All words that can be substituted in a given syntactic position constitute one positional class. The first test box was filled with words capable of occupying a position in a sentence. All words that can be substituted in this position without changing the structural meaning, Frieze calls the words of the first positional class. In traditional grammar terms, these are words in subject position in a simple declarative sentence.

In the second frame, all words were substituted in position (i.e., in the position of the predicate verb in the personal form). These words constituted the second positional class.

The third positional class is the position of the adjective in the first test box, i.e. in the position of the prepositive definition and the nominal part of the predicate.

The fourth positional class almost coincides with traditional adverbs that can modify 
the verb.

In addition to these four positional classes, Frieze identifies 15 more groups of formal words for which he uses letter designations (A, B, $\mathrm{C}, \ldots \mathrm{O})$. Group A includes all determinants, determinatives, i.e. all words that can appear in the definite article position in the first test box. For group B, take all those words that can stand in the position possible in the following frame: the concert (can) be good. This includes modal and auxiliary verbs. Group $\mathrm{C}$ includes only one word (no) (negative particle, in traditional terminology). For group D, C. Freese proposes to combine all words that can occur in a position very immediately before a word of the third positional class, they signal a certain degree of quality. When isolating this group of words, Fries still has to resort to meaning $[5,147 ; 6,7]$.

Four positional classes contain thousands of units, words of 15 groups - 154 units (very uneven division). The disadvantages of the classification should be attributed to its mutual intersection, since the same word appears in several digits. At the same time, C. Freese consistently applies the substitution method and obtains interesting data on the distribution of words and their syntactic valence (compatibility).

\section{Referens}

[1] Reformatskiy A. A. Vvedeniye v yazikovedeniye. -M., 1967. -S. 58.

[2] Zinder L. R. Fonema i morfema. - Problemi lingvisticheskoy tipologii i struktur yazika. L., 1977.-S. 124.

[3] Ivanova A. N. Struktura mestoimennosootnositelnix predlojeniy frazeologicheskogo tipa $\mathrm{V}$ vostochno slavyanskix yazikax. - Metod. prepod. rus. yaz. i lit. -Kiyev, 1975. vip. 10.-S. 161 -167.

[4] Ivanova T. A. Nekotoriye aspekti sopostavitelnogo analiza posessivnix konstruksiy. ( $\mathrm{Na}$ materiale sovremennix slavyanskix literaturnix yazikov). № 23. -S.
$148-152$.

[5] Vinogradov V.V. Russkiy yazik. Grammaticheskoye ucheniye o slove. M., L., 1947, 2 -ye izd. -M., 1972.-S. 147.

[6] Saiidyrakhimova, D.S., \& Zhakypova, D.M. (2016) General Teoretical in synchronikal typological leaming of english adverbs. International Scientific Journal Theoretical \& Applied ScienceY. Philadelphia, USA, №2 (58), (pp. 16-19).

[7] Saiidyrakhimova, D.S., Jusupova. D.Y., Narmatova. G.X., \& Sayidirahimova N.S. (2020). Vliyaniye anglitsizmov na razvitiye kirgizskoy leksiki. International Journal ofresearch in Economics and Social Sciences (IJRESS) Available online at:http://euroasiapub.org. Vol.10 Issue 11. (pp.63-74).

[8] Sayidirahimova, N.S., \& Kabulova, U.S (2020). General Theoretical Aspects In Synchronical Typological Learning Of English Adverbs (Adverb Goals). International Journal of Research Available at https://edupediapublications.org/journals. Available online: http://edupediapublications.org/journals/inde X.php/IJR/ R. -Indiya, (pp. 384-398).

[9] Esonovna, L. D., Anvarovna, N. M., Sayidmahamadovna, S. N., Alimullaevna, N. F., \& Kakhramanovna, S. N. (2020). Pragmatic features of official texts and documents of the uzbek language. ANGLISTICUM. Journal of the Association-Institute for English Language and American Studies, 9(7), 27-34.

[10] Sayidirakhimova, D.S., Kabulova, U.S., Sayidirahimova, N.S., \& Tadjibayeva, M.A. (2020). Problem of adverbs synchronicallytypological investigation of grammatical categories in unrelated languages. International Journal of Research in Economics and Social Sciences (IJRESS). Available online at: http://euroasiapub.org Vol. 10 Issue 11, (pp.81-89). 
[11] Akhmedova, N. Sh. (2020). Expression of the concept of motherland in uzbek language. Theoretical \& Applied Science. International Scientific Journal. - Filadelfiya, 2020. Issue: 05 Volume: 85.

[12] Sayidirahimova, N.S. (2020) Semantic classification of the syntax antonyms of uzbek language. International Scientific Journal.Theoretical \& Applied Scienceю. Philadelphia, USA. (pp. 671-673).

[13] Lutfullayeva, D. E. (2016). The Role Of Associative Experimental Method In The StudyOf Human Linguistic Memory. In Современные проблемы тюркологии: язык-литература-культура (рp. 452-457).

[14] Nig'monov, A., Rustamiy, S., Nasirova, M., \& Djafarov, B. Lexical Parallels Used In The Quatrains In The Dīwān Lughāt Al-Turk. European Journal of Molecular \& Clinical Medicine, 7(03), 2020.

[15] Arifdjanov, Z. T. (2020). THE STRUCTURE OF PERSIAN VERBS AND THEIR ROLE IN WORD FORMATION. Theoretical \& Applied Science, (7), 420-423.

[16] Лутфуллаева Д., Давлатова Р., Тожибоев Б. Ассоциативный словарь узбекского языка.-Ташкент:"

NAVOIY

UNIVERSITETI". - 2019.

[17] Лутфуллаева, Д. Э., \& Сапарниязова, М. (2020). Проблема ассоциативного подхода к языку на современном этапе узбекского языкознания. Вопросы когнитивной лингвистики, (2), 139-146.

[18] Arifdjanov, Z. (2020). The semantic groups of prefixal verbs in the persian language and their functional equivalents (using the verb [bar-dāštan] as an example). The Light of Islam, 2020(2), 68-74.

[19] Лутфуллаева, Д. Э., \& Сапарниязова, М. (2020). Национальная технология создания названия (имени) в узбекском языке. Научный электронный журнал Меридиан, (6), 327-329.
[20] Saiidyrakhimova, D. S., \& Daanagul, Z.N. Sayidirahimova, N.S (2020). THE ISSUE RELATED TO THE THEORY OF SPEECH PARTS AND THEIR CLASSIFICATION ON THE MATERIAL OF LEXIC UNITS (IN THE MATERIAL OF ADVERBS). PalArch's Journal of Archaeology of Egypt/Egyptology, 17(7), 6753-6757.

[21] Arifdjanov, Z. (2020). Functional equivalents of the simple verb خواستن [xāstan] and their formal invariants. The Light of Islam, 2020(1), 163-170.

[22] Akhmedova Nargiza Shikhnazarovna. Linguo-cultural characteristics in uzbek referential units //EPRA International Journal of Multidisciplinary Research (SJIF Impact Factor :5.614) Volume: 6 Issue: 1 January 2020.

https://eprajournals.com/jpanel/upload/914p m 31.EPRA\%20JOURNALS\%20-3950.

[23] Sayidmahamadovna, S.N., Kabulova, Umida Saiidmakhadovna, K., \& Tursunova Odinaxon Azimjanovna, M. (2020). AMBIGUITIES IN UZBEK LANGUAGESYNTACTIC HOMONYMS. PalArch's Journal of Archaeology of Egypt/Egyptology, 17(7), 9652-9660.

[25] Rustamiy, S. (2018). Typological peculiarties of science of balaghah, rhetoric and stylistics. The Light of Islam, 2018(1), 16. 